\title{
THE CONFIDENTIALITY OF MEDICAL RECORDS: INFORMATIONAL AUTONOMY, PATIENT PRIVACY, AND THE LAW
}

\section{Joan Loughrey, Lecturer, School of Law, University of Leeds INTRODUCTION}

This article examines critically the level of protection currently afforded to medical privacy by the law of confidence in situations involving the use and handling of personal information by NHS bodies. Patient data is used by the NHS for a broad range of purposes, not limited to care of the patient, including administrative, auditing and educational purposes. ${ }^{1}$

A number of developments in recent years have combined to threaten patient privacy. The increasing utilisation of information technology is making the collation and dissemination of patient data easier both within and without the NHS. Electronic Care Records are being introduced which will contain a lifelong record of a patient's health and healthcare. ${ }^{2}$ Just as locating patient information becomes easier, the nature of that information, and its sensitivity, is altering as developments in the science of genetics impacts on health care. ${ }^{3}$ Furthermore recent organizational reforms in the NHS may undermine medical privacy. ${ }^{4}$ There have been various legislative initiatives aimed at removing legal obstacles to the transmission of patient data. ${ }^{5} \mathrm{New}$ Labour's drive for better integrated public services has required greater sharing of information between public agencies for a wide range of administrative purposes. ${ }^{6}$ The Government has indicated that the data collected under improved information systems will facilitate NHS management processes, will be made available to local authority social

1 See Department of Health, Confidentiality NHS Code of Practice (November 2003) Annex C, which sets out a wide range of situations in which patient data may be disclosed by the NHS.

2 It is envisaged that, at some point, the Electronic Patient Record may include the results of tests carried out upon patients pre-birth: Human Genetics Commission, Inside Information, Balancing Interests in the Use of Personal Genetic Information (May 2002) Ch.4, para.4.21.

3 For a detailed review of the legal and ethical aspects of privacy in the context of genetic information see G.T. Laurie, Genetic Privacy: a Challenge to MedicoLegal Norms (2002).

4 Perri 6, C. Raab and C. Bellamy, "Joined-Up Government and Privacy in the United Kingdom: Managing Tensions Between Data Protection and Social Policy: Part I" (2005) 83 Public Administration 111 at p.114.

5 Notably, the Health and Social Care Act 2000, s.60, the Health Service (Control of Patient Information) Regulations 2002, SI 2002/1438 and the Health and Social Care (Community Health and Standards) Act 2003. For a critique of the first two, which are intended to be transitional measures, see P. Case, "Confidence Matters: The Rise and Fall of Informational Autonomy in Medical Law" (2003) 11 Medical Law Review 208.

6 Perri 6, Raab and Bellamy, n.4 above, at pp 112-113. 
services, and will further constitute an exploitable commercial asset. ${ }^{7}$ At the same time, given demographic changes and the growing significance of health services in the lives of many citizens, the ability of patients to control medical information is arguably an increasingly important aspect of individual autonomy.

These developments are problematic for a number of reasons. The empirical evidence in Britain suggests that both communities and patients place a high value on medical privacy. ${ }^{8}$ While most people have no objection to the disclosure of information within the NHS for the purpose of their own treatment, there is general unease about the sharing of such data more widely with other healthcare professionals, social workers, NHS managers or support staff. ${ }^{9}$ The Government's own research shows that individuals do not feel positively about the disclosure of medical information to achieve claimed indirect benefits such as better functioning of public services, or for purposes such as audit. ${ }^{10}$ Furthermore, a majority of individuals wish to have the opportunity to consent to the various uses made of their healthcare data, and believe that refusals of consent should be respected. ${ }^{11}$ The current law in this area may therefore be regarded as deficient to the extent that it fails to give effect to public expectations about respect for informational autonomy and control of access to health records.

The principle that an individual's autonomy should be respected is fundamental to medical law and ethics. It requires that an individual is able to make decisions about their life free from coercion or impediment and that such decisions are respected. Informational autonomy constitutes the ability

7 Department of Health, Building the Information Core-Implementing the NHS Plan (January 2001) para.4.5, para.5.6. and para.6.14 respectively. See also Department of Health, Confidentiality NHS Code of Practice (November 2003) Annex C. For a discussion of the growing pressures on informational privacy see R. Pattenden, The Law of Professional-Client Confidentiality (2003) Ch.2; Perri 6, Raab and Bellamy, n.4 above.

8 European Opinion Research Group (Special Eurobarometer), Data Protection (December 2003) at p.7: $75 \%$ of the British public were fairly or very concerned that their privacy should be protected.

9 For a comprehensive survey of studies on the public attitude to medical privacy see NHS Information Authority, ERDIP Evaluation Project: N5-Patient Consent and Confidentiality Study Report (16 ${ }^{\text {th }}$ May 2002): one study, involving 1239 responses, found that $40 \%$ objected to disclosure to hospital managers, social workers and practice support staff: at 29; NHS Information Authority, Share with Care! People's views on Consent and Confidentiality of Patient Information (October 2002) at pp.9, 13-14, 26: only 17\% were happy for NHS managers to access records.

${ }^{10}$ Performance and Innovation Unit, Privacy and Data Sharing: the Way Forward for Public Services, Annex C para. C27 (hereafter "PIU"), although the report noted 1999 research by the National Consumer Council which had concluded that there was little public concern about patient records circulating within the NHS: at para.C11.

11 NHS Information Authority, n.9 above, at pp.9, 13-14, 26. See also M. Robling, K. Hood, H. Houston, R. Pill, J. Fay and H. Evans, "Public attitudes towards the use of primary care patient record data in medical research without consent: a qualitative study" (2004) 30 Journal of Medical Ethics 104; PIU, n.10 above, at para.C23. 
"to control what is known (and by whom) regarding oneself and one's activities." 12 It has been argued that this "informational self determination" constitutes the core interest protected by the law of confidence. ${ }^{13}$ When an autonomous person's informational privacy has been breached, that is, where her personal private information has been disclosed without her consent, there is a failure to respect her autonomy.

A failure to respect autonomy is morally objectionable because it fails to respect an individual as a person and as a rational moral agent ${ }^{14}$ and uses her as a means to an end rather than as an end in herself. ${ }^{15}$ Consequently, insofar as the law permits the disclosure of health care records without giving due weight to the principle of informational autonomy, it may be regarded as morally deficient.

Against this background the paper argues that the law fails adequately to protect individual interests in medical privacy and that, contrary to expectations generated by the Human Rights Act 1998, there is little difference between the protection of informational autonomy under Article 8 jurisprudence and that provided by the common law. Despite some indications that the courts are beginning to recognise the dignitary interests underpinning the law of confidence, this is unlikely to result in increased protection of patient privacy and informational autonomy due to the reluctance of the judiciary to intervene in administrative decision-making where disclosure occurs or is sought by public bodies 'in the public interest'.

The main focus of the paper is on the common law of confidence in the context of changes brought about under the Human Rights Act 1998 ("the HRA"). Although the Data Protection Act 1998 ("DPA") may be interpreted to give effect to Article 8 rights to informational privacy ${ }^{16}$ and although it introduced significant safeguards directed at the manner in which public bodies deal with data, it may have little to add to the common law in the extent to which it advances informational autonomy. While it is true that it grants patients additional rights to control their data including a right to prevent its use, ${ }^{17}$ these rights will be of little practical use in the medical context since there remains a lack of patient awareness of the range of

12 J.R. Pennock, "Introduction" in J.R. Pennock and J.W. Chapman (eds), Privacy, NOMOS XIII (1971), p.xiii.

13 G. Phillipson and H. Fenwick, "Breach of Confidence as a Privacy Remedy in the Human Rights Act Era" (2000) 63 MLR 660 at p.662. It should be noted that informational autonomy and privacy are not the same. For example privacy may be protected in circumstances where individuals have been given no rights to control information access and, it will be seen, protected for reasons other than concerns with informational autonomy. However a key aspect of recognising informational autonomy is that it not only provides a reason for respecting the privacy of the autonomous, it requires that control over information is exercised by the persons to whom it relates.

14 S. Benn, "Privacy, Freedom and Respect for Persons" in Pennock and Chapman, n.12 above, Ch.1; J.S. Mill, On Liberty (1869) Ch.I and Ch.III.

15 I. Kant, Foundations of the Metaphysics of Morals, (1959) (trans. Lewis White Beck).

16 As a result of the courts' obligation to interpret legislation compatibly with the Convention wherever possible: Human Rights Act 1998, s.3.

17 Data Protection Act 1998, s.10. 
disclosures which may take place. ${ }^{18}$ Patients are not, therefore, in a position to exercise their rights under the DPA to prevent disclosure. Should they discover subsequently that disclosure has occurred, only the law of confidence provides them with a remedy. Under the DPA, once information is released, compensation for distress alone will usually be unavailable, a restriction which casts doubt on its efficacy as a remedy for invasions of privacy. ${ }^{19}$ Furthermore the DPA contains a range of defences and exceptions which legitimise the use of data without patient consent and even in the face of patient objections, which undermine the extent to which it can be relied upon to advance informational autonomy. ${ }^{20}$ However in all cases processing must be lawful, that is, it must not be carried out in breach of an obligation of confidence. ${ }^{21}$ Consequently the law of confidence occupies a central role in the protection of privacy.

The article is structured as follows: firstly the rationales for the protection of medical confidentiality both before and after the Human Rights Act 1998 will be assessed including the extent to which the value of informational autonomy has been recognised by the law and whether such recognition is necessitated by Article 8 of the HRA. Secondly the scope of the public interest defence and Article 8(2) justifications for disclosure will be examined to ascertain whether the need to justify privacy interferences by reference to Article 8(2) affects the protection afforded to privacy. Finally, to the extent that informational autonomy is acknowledged, the paper will analyse why it will not result in better protection for privacy where access to information is sought by the State.

\section{MEDICAL CONFIDENTIALITY AND THE PROTECTION OF AUTONOMY}

\section{Pre- Human Rights Act 1998: the Public Interest Rationale}

Briefly the traditional formulation of the action for breach of confidence was, "the information ... must have the necessary quality of confidence about it. Secondly, that information must have been imparted in circumstances importing an obligation of confidence. Thirdly, there must be an

18 NHS Information Authority, n.9 above.

19 Data Protection Act 1998, s.13. There are exceptions where the data has been processed for journalism, artistic purposes or literary purposes: Data Protection Act 1998, s.3; See criticism in Martin v United Kingdom (2003) 37 E.H.R.R. C.D. 91 , at 100 .

${ }^{20}$ For example, a person can only prevent processing if they are able to show that it will cause substantial and unwarranted distress: Data Protection Act 1998 s.10. For further discussion of the operation of the DPA in the medical context see M. Brazier, Medicine Patients and the Law (2003), pp. 76-77; A. Grubb, Principles of Medical Law (2004), paras.9.192-9.193. See also L. Hagger, S. Woods and P. Barrow, "Autonomy and Audit-Striking the Balance" (2004) 6 Medical Law International 105 which demonstrates how the DPA can be interpreted to permit the use of data without consent.

21 Data Protection Act 1998 Sch.1. Information Commissioner, Use and Disclosure of Health Data: Guidance on the Application of the Data Protection Act 1998 (May 2002) at Ch.4. 
unauthorised use of that information to the detriment of the party communicating it." 22

In the context of medical information, the doctor/patient relationship is one of trust and has long been protected by the law of confidence. ${ }^{23}$ In relation to other health care professionals, the therapeutic context has been held to be sufficient to import an obligation of confidence, whether or not health care professionals have treated the patient. ${ }^{24}$

Historically, the public interest has dominated judicial explanations for protecting confidentiality. ${ }^{25}$ Examples include $X \mathrm{v} Y$ in which a newspaper sought to publish the identities of two GPs who had been diagnosed with AIDS. $^{26}$ The information had probably been disclosed by a hospital employee in breach of a contractual obligation of confidence. The hospital was granted an injunction on the basis that there was a public interest in protecting confidentiality which comprised encouraging persons to come forward for treatment and the consequent protection of public health. ${ }^{27}$

Subsequently, in $W \mathrm{v}$ Egdell, an expert medical report concerning a dangerous prisoner was disclosed in breach of confidence. The Court of Appeal rejected the argument, accepted at first instance, that the right to confidence was based upon an individual's private interest. The Court, echoing the reasoning in $X \vee Y$, affirmed that the maintenance of confidentiality was based upon the public interest. ${ }^{28}$

Given the nature of this rationale, the common law naturally developed a defence to an action for breach of confidence where it could be shown that disclosure was, overall, in the public interest. ${ }^{29}$ The scope of the public interest defence is unclear and, prior to the HRA, it had only been judicially recognised as operating to justify disclosures to protect the public from harm, to prevent or detect a crime, ${ }^{30}$ or to disclose an iniquity, ${ }^{31}$ although in the context of medical confidentiality, the precise scope of the last two categories remains uncertain. It is unclear, for example, whether the public interest defence is confined to serious crime. Professional guidance leaves

22 Coco v A.N. Clark (Engineers) Ltd [1969] R.P.C. 41, at 47. This paper will not analyse in detail the elements of the action in confidence nor its subsequent development. This has been dealt with elsewhere. See Grubb, n.20 above, at Ch.9.

23 Hunter v Mann [1974] 1 Q.B. 767, at 772; $X$ v $Y$ [1988] 2 All E.R. 648; $W$ v Egdell [1990] Ch.359; AG v Guardian Newspapers (No. 2) [1990] 1 A.C. 109 H.L., at 255 (Lord Keith).

24 Re C (a minor) (wardship: medical treatment) [1989] 2 All E.R. 791, at 795.

25 Attorney General v Guardian Newspapers Ltd (No 2) n.20 above, at 256 (Lord Keith), at 269 (Lord Griffiths), at 281 (Lord Goff).

26 n. 20 above.

27 There was also a public interest in encouraging loyalty in health service employees to their employer.

28 n. 20 above, at 416 (Sir Stephen Brown P.), at 420 (Bingham L.J.).

29 Attorney General v Guardian Newspapers (No 2), n.20 above, at 269 (Lord Griffiths), at 282 (Lord Goff); $X \vee Y$, n.20 above; $W$ v Egdell, n.20 above.

$30 W$ v Egdell, n.20 above, at 425.

31 Beloff v Pressdram Ltd [1973] 1 All E.R. 241; Initial Services v Putterill [1968] Q.B. 396. 
the matter to the discretion of the health care professionals and the case law has not addressed the point. ${ }^{32}$

It was also unclear whether uses of patient data for NHS purposes, such as teaching, financial and clinical audit, management and administrative purposes and medical research could be justified on the basis of this defence. ${ }^{33}$ There had been dicta outside the sphere of medical confidentiality which suggested that a broad public interest defence of just cause or excuse existed which could legitimate disclosures where the public interest in disclosure outweighed the interest in maintaining confidence, even though no wrongdoing is involved. ${ }^{34}$ If correct, these comments could have justified a broad range of disclosures.

In the end, the legality of such uses was not tested. This was not because such disclosures did not occur but rather because patients did not litigate over them. However, had a challenge to such uses been mounted, it is likely to have been unsuccessful. There are problems in seeking to protect rights by appealing to public interest justifications. Lyons argues that basing a legal right upon utilitarian grounds cannot accommodate the right having moral force. The presumptive moral force of a right means that direct utilitarian arguments, which would otherwise justify conduct, must be excluded where the conduct interferes with the right. However where a right is justified on the basis that it promotes utility it can have no presumptive force, as considerations of direct utility will always be relevant in determining whether the right should be respected or not. ${ }^{35}$ It might be

32 Although, in Campbell v M.G.N., the defendant relied on Ms Campbell's presumptive criminality in possessing and using Class A drugs to justify publication, the point was not addressed by the court: [2003] EWCA Civ 1373; [2003] Q.B. 633 at 676. In the only other medical case which raises the point, $W$ y Egdell, n.20 above, there was a real risk to public safety should the types of offence anticipated have occurred. The Department of Health, n.1 above, at pp.34-35, advises that disclosure can occur for the detection, investigation and punishment of serious crime and/or to prevent serious harm, which includes crimes involving substantial financial gain or loss. The guidance also indicates that disclosure may take place where there would be a significant benefit to the public. See also GMC, Confidentiality: Protecting and Providing Information (April 2004), at paras. 22-27.

33 In R. v Department of Health, ex p. Source Informatics Ltd [2001] Q.B. 424, at 444, Simon Brown L.J. considered, albeit reluctantly, that the defence could cover uses for management purposes. See also A Health Authority v X [2001] 2 F.L.R. 673, at 696; I. Kennedy and A. Grubb, Medical Law (2002), p.1118; GMC, Research: The Role and Responsibilities of Doctors (2002), at paras. 37-39.

34 Fraser v Evans [1969] 1 All E.R. 8, at 10; Woodward v Hutchins [1977] 2 All E.R. 751, at 753 (Lord Denning); Lion Laboratories Ltd v Evans [1985] Q.B. 526, at 536 (Stephenson L.J.); D v NSPCC [1978] A.C. 171, at 230 (Lord Hailsham); Attorney General v Guardian Newspapers Ltd (No. 2), n.23 above, at 282 (Lord Goff). For a review of the case-law see Pattenden, n.7 above, at paras. 11.4111.52. Both Wacks and Gurry argue that the cases in which such a suggestion has been made are of weak authority: the defences of disclosure of an iniquity or prevention of harm were also available, or there existed some element of wrongdoing or risk to the public: R. Wacks, Personal Information, Privacy and the Law (1989), pp.115-117; F. Gurry, Breach of Confidence (1984), pp.334-341.

35 D. Lyons, "Utility and Rights" in J. Waldron (ed.), Theories of Rights (1984) p.110, at p.113 and generally. 
argued that the legal right to confidence would prevail over those considerations of general utility which do not fall within the scope of the public interest defence but it would be vulnerable to arguments that it should be set aside where the public interest would be better served by doing so. It would therefore be logical for the courts to give the public interest defence a broad interpretation. In addition where the considerations of general welfare do fall within the parameters of the public interest, then a right to confidence founded on the public interest can never provide a reason for overriding these considerations if general welfare, in the form of the public interest, is, in fact, advanced overall by disclosure. The strength of such a right depends upon the scope and weight of the public interest defence rather than upon the right itself. Furthermore this approach is vulnerable to the common criticisms levelled at utilitarianism. As it is not possible to objectively measure one outcome against another in order to ascertain which maximises overall welfare, the protection afforded to confidential information on this basis is likely to be subjective, ad hoc and uncertain.

In summary, prior to the Human Rights Act 1998, informational autonomy was poorly respected as a matter of practice in the NHS. Furthermore, it was not a value promoted by the law. Moreover the strength of the legal right to medical confidentiality, that is, its ability to withstand arguments in favour of disclosure in order to benefit the public, though untested, was probably weak.

\section{After the Human Rights Act 1998: The Three Rationales}

Following the HRA, the law of confidence has developed as the main vehicle for protecting the Article 8 right to a private life. ${ }^{36}$ This has resulted in the strengthening of the action for breach of confidence in a number of respects. ${ }^{37}$ For example, the obligation of confidence can now arise independently of any relationship of confidence, where the recipient of the information knows or ought reasonably to know that the information is confidential. ${ }^{38}$ Where an unjustified breach is established damages for mental distress are now available. ${ }^{39}$ However the action for breach of confidence continues to provide only imperfect protection for informational privacy. ${ }^{40}$ The obtaining of information by the NHS (for example, where it is

36 Campbell v M.G.N. [2004] UKHL 22; [2004] 2 A.C. 457, at 465 (Lord Nicholls), at 472-473 (Lord Hoffmann), at 486 (Lord Hope); Douglas v Hello [2005] EWCA Civ 595, at para.53.

37 Although, conversely, the insistence that privacy rights must be shoehorned into the action for breach of confidence has weakened the potential scope of Article 8 and the protection of privacy: Peck v United Kingdom (2003) 36 E.H.R.R. 41, at paras. 111-113;

38 Campbell v M.G.N., n.36 above.

39 Cornelius v De Taranto [2002] E.M.L.R. 6; Douglas v Hello! Ltd (No 3) [2003] EWHC 786; [2003] 3 All E.R. 996, affirmed on appeal [2005] EWCA Civ 595; [2005] 2 F.C.R. 487. Campbell v M.G.N., n.36 above. For an overview of developments in this area see Pattenden, n.7 above, at paras. 8.55-8.65 and Update http://www.uea.ac.uk/law/resources/8-28.htm (last visited 24 April 2005).

40 And wholly inadequate for protecting other forms of privacy such as freedom from intrusion and spatial privacy: see Wainwright v Home Office [2003] UKHL 53; [2004] 2 A.C. 406, Martin v UK (2003) 37 E.H.R.R. C.D. 91 at 100 and Laurie, n. 2 above. 
obtained as the result of clinical observation) and its retention, rather than use or disclosure may not be a breach of confidence for example, nor is legislatively authorised disclosure, although this may be challenged as an interference with Article 8 rights. ${ }^{41}$

It has been argued that the incorporation of Article 8 requires greater protection of the value of informational autonomy. This view stems from equating the protection of informational privacy with the protection of informational autonomy and the right to control the release of personal information. ${ }^{42}$

It does not follow however that because the law is now concerned with protecting informational privacy, albeit imperfectly, it must also be concerned with the protection of informational autonomy. There is little consensus on what privacy is, or why it should be protected, and competing explanations of its rationale are available which could equally well underpin the law. ${ }^{43}$ Some consider that privacy is worthy of protection on utilitarian grounds, that invasions of privacy may hinder the good life, for example, by hindering the pursuit of desirable private activities which produce social goods. ${ }^{44}$ Others justify the protection of privacy because it is instrumental in protecting other values such as dignity and respect for persons. ${ }^{45}$ It can be argued, for example, that the protection of privacy is instrumental in protecting mental integrity.

In fact, while informational autonomy has received some recognition from the judiciary, it competes as a rationale with two others. The utilitarian rationale continues to appear in the form of public interest arguments in support of the obligation of confidence while a third rationale has developed in the form of the protection of mental and physical integrity. The degree to which these rationales feature in the case law, and the extent to which their

41 In R. (Marper) v Chief Constable of South Yorkshire [2004] UKHL 39; [2004] 1 W.L.R. 2196, the House of Lords considered that the retention of samples and fingerprints did not even infringe Article 8 but in Chare (nee Jullien) v France (1991) 71 D.R. 141, the European Commission held that the retention of a medical file did. See also J. Morgan, "Privacy, Confidence and Horizontal Effect: "Hello" trouble" (2003) 62 CL.J. 444.

42 See for example, A. Westin, Privacy and Freedom (1967) 7; E.L. Beardsley, "Privacy, Autonomy and Selective Disclosure" and H. Gross, "Privacy and Autonomy" in Pennock and Chapman (eds.), n.12 above, Ch. 3 and Ch. 9; L. Lusky, "Invasion of Privacy: a Classification of Concepts" (1972) 72 Columbia Law Review 693; D. Feldman, "Secrecy, Dignity, or Autonomy? Views of Privacy as a Civil Liberty" (1994) Current Legal Problems 41; R. Singh, "Privacy and the Media: the Impact of the Human Rights Bill" in B. Markesinis (ed.), Protecting Privacy (1999) p.169; Phillipson and Fenwick, n.13 above, at p.674.

43 See overview R. Wacks, The Protection of Privacy (1980), Ch. 1 and Laurie, n.2 above, Ch. 2.

$44 \mathrm{M}$. Weinstein reviews the range of arguments on this point in "The Uses of Privacy in the Good Life" in Pennock and Chapman (eds.), n.12 above, Ch. 5.

45 B. Neill, "Privacy: A Challenge for the Next Century" in Markesinis, n.42 above, at pp.22, 28; E.J. Bloustein, "Privacy as an Aspect of Human Dignity: An Answer to Dean Prosser" [1964] 39 New York University Law Review 962; Feldman, n.42 above, at p.58, who also links it with the protection of autonomy; S. Benn, "Privacy, Freedom and Respect for Persons" in Pennock and Chapman, n.12 above, Ch. 1; Laurie, n.2 above, at pp.214, 248. 
recognition is compatible with the approach of the Strasbourg court to medical privacy, will now be examined.

\section{(a) The public interest}

In Ashworth Hospital Authority v MGN Ltd., Lord Phillips stated that:

"The disclosure of confidential medical records to the press is misconduct that is not merely of concern to the individual establishment in which it occurs. It is an attack on an area of confidentiality which should be safeguarded in any democratic society. The protection of patient information is of vital concern to the National Health Service and, I suspect, to health services throughout Europe." 46

In the House of Lords, Lord Woolf also recognised the community interest in protecting medical confidentiality so as to encourage persons to come forward for treatment. ${ }^{47}$

The problems of basing a right to confidence upon the public interest have been explored. However a feature of case-law post the HRA has been the protection of medical confidentiality against press disclosures, including in those cases where a public interest rationale has been cited. ${ }^{48}$ A conventional explanation of these cases is that medical confidentiality receives special protection by the courts. Given that the courts consider that freedom of the press is a powerful value to be protected and upheld, if they uphold medical confidentiality on public interest grounds despite such a weighty conflicting public interest, it might be argued that, in fact, this demonstrates that the public interest in confidentiality provides a strong basis for the protection of patient privacy. ${ }^{49}$

However, when the case law on medical confidences is viewed as a whole, it is apparent that it is the nature of the disclosure, rather than the nature of the information alone, which is significant. In non-media cases, medical confidentiality is poorly protected. The explanation for this lies in considerations of utility. If medical confidences are protected in order to encourage people to come forward for treatment without fear of disclosure of their records, it follows that where a particular disclosure will not affect public trust, utility may not require adherence to a rule of confidence. ${ }^{50}$ Utility does not dictate disclosure in such circumstances, nor does the rule imposing an obligation of confidence disappear. Clearly, the courts have concluded that the public interest is served by having a general rule upholding medical confidentiality, although it is subject to exceptions

46 [2001] 1 W.L.R. 515, at [99].

47 [2002] 1 W.L.R. 2033, at 2051-2052, citing $Z$ v Finland (1998) 25 E.H.R.R. 371 at para.95. See also $X \vee A$ Health Authority [2002] 2 All E.R. 780, at 784; $H(a$ Healthcare Worker) v Associated Newspapers Ltd [2002] E.M.L.R. 23 at para.27.

48 Ashworth Hospital Authority v M.G.N. Ltd, n.47 above; Campbell v M.G.N., n.36 above, at 474 (Lord Hope), at 487 (Baroness Hale).

49 For strong statements of the importance of press freedom see $R$ v Central Independent Television plc [1994] Fam. 192, at 203; A v B Plc [2002] EWCA Civ 337; [2003] Q.B. 195, at 205.

50 See H. Lesser and Z. Pickup, "Law, Ethics and Confidentiality" (1990) 17 Journal of Law and Society 17. 
Where a rule exists, reasons must be advanced if it is to be set aside in a particular case. If no satisfactory reasons are established, the rule will be upheld. ${ }^{51}$ However, provided that some good reason for disclosure can be demonstrated, the rule will be easier to set aside when it is operating in this default mode than when the circumstances of a particular case lend it some content.

The courts have not considered that the public interest in medical confidentiality is affected by limited disclosures to public authorities and have dismissed the argument that disclosure should not occur because it could deter the individual(s) to whom the information relates from seeking further treatment. ${ }^{52}$ In $\operatorname{Re} C$ (A Minor) (Evidence: Confidential Information), in permitting the use of confidential medical information in adoption proceedings, Boothman J. commented, "If I allow this affidavit in evidence, it is not going to dent public confidence in the medical profession. It is not going to result in patients having less confidence in their doctors. The mother, no doubt, will have less confidence, but the public at large certainly won't." 53 As the courts have denied that the interest underpinning the right to confidence has been affected in such cases, the rule has been easy to set aside. Similarly in $Z$ v Finland the European Court's finding that disclosure for the purposes of the investigation would not impact on the public interest in medical privacy influenced the conclusion that the disclosures were legitimate. ${ }^{54}$

Conversely press publication of medical information is a highly public breach of confidentiality. A failure to penalise and deter such conduct might seriously undermine patient confidence in the protection of medical information and so damage the public interest which the law is concerned to protect. In such cases the rule requiring that confidentiality should be respected would be operating in substantive, rather than default, mode and would therefore be more difficult to set aside.

Again, where disclosure to bodies other than the press has been authorised, the courts have emphasised that disclosure was made to an appropriate entity and that the material would remain confidential in the hands of the recipient. ${ }^{55}$ Dissemination was unlikely to attract much public attention and so the public interest in confidentiality was unlikely to be affected.

51 There is a view that utilitarianism, even act utilitarianism, can accommodate rules, see for example, J. Rawls, "Two Concepts of Rules" in P. Foot (ed), Theories of Ethics (1967) p.144; R.G. Frey, "Act-Utilitarianism" in R.G. Frey (ed), Utility and Rights (1984), p.61. There are doubters: J.J.C. Smart, "Extreme and Restricted Utilitarianism" in Foot, ibid, at p.171.

$52 W \vee$ Egdell, $n .23$ above, at 424.

53 Cited in judgment of Sir Stephen Brown P, [1991] 2 F.L.R. 478, at 481. The Court of Appeal upheld the decision. See also Gunn-Russo v Nugent Care Society [2001] EWHC Admin 566; [2002] 1 F.L.R. 1.

54 (1998) 25 E.H.R.R. 371 at para. 104.

55 A Health Authority v X, n.33 above, at 692; Woolgar v Chief Constable of the Sussex Police [1999] 3 All E.R. 604, at 606, 615; R. (on the application of S) v Plymouth City Council [2002] EWCA Civ 388; [2002] 1 W.L.R. 2583, at 2599; Re $R$ (a child) [2004] EWHC 2085. Although an emphasis on restrictive disclosure forms part of the less political aspect of the test of necessity (see subsequent text) and therefore will be emphasised by the courts where they must test the necessity 
Thus, despite the weight given to the freedom of the press and freedom of expression, there are strong utilitarian reasons why disclosures to the press should be treated more restrictively than disclosures for less publicly obvious purposes, even though the public interest justifying the latter might not be as strong as the public interest in free speech. The former are more likely to undermine the public interest protected by the obligation of medical confidence than the latter. It follows that the media cases are an unreliable guide to the capacity of the law to protect informational privacy in nonmedia cases.

The utilitarian rationale is not concerned with advancing informational autonomy. This might, at first, be considered to be incompatible with an approach informed by Article 8 jurisprudence, assuming that this requires domestic courts to accord more weight to informational autonomy. ${ }^{56}$ However the European case law on medical privacy does not appear to equate informational privacy with informational autonomy but with utilitarian concerns.

Thus in $Z \mathrm{v}$ Finland, the European Court, while articulating the fundamental importance of protecting medical privacy, explained that:

"It is crucial not only to respect the privacy of a patient, but also to preserve his or her confidence in the medical profession and in health services in general. Without such protection those in need of medical assistance may be deterred from revealing such information of a personal and intimate nature as may be necessary in order to receive appropriate treatment and, even, from seeking such assistance thereby endangering their own health and, in the case of transmissible diseases, that of the community." 57

The Court also commented that a failure to protect the privacy of medical information would affect not only the patient but would also undermine the community's efforts to contain the AIDS pandemic..$^{58}$

These are consequentialist justifications which little to do with promoting patient autonomy. It is true that in relation to other aspects of Article 8, the Court has been more willing to identify the interests protected as being autonomy based or in the nature of dignitary interests. ${ }^{59}$ Given the wide spectrum of situations falling under Article 8 and its open-ended nature, it may not follow that the principles articulated in dissimilar cases will be

of an interference but do not wish to engage on a more substantive review of it, this cannot wholly explain this legal development as it predates the Human Rights Act 1998: Wv Egdell, n.23 above, at 416; Re C (A Minor) (Evidence: Confidential Information), n.53 above, at 483 .

56 Phillipson and Fenwick, n.13 above, at pp. 662-663. G. Phillipson, "Transforming Breach of Confidence? Towards a Common Law Right of Privacy under the Human Rights Act" (2003) 66 MLR 726 at p.732. See also Case, n.5 above, at p.221.

57 n.54 above, at para.95.

$58 \mathrm{ibid}$, at paras. 96 - 97. See also $M S$ v Sweden (1999) 28 E.H.R.R. 313, at para.41.

59 Pretty v United Kingdom (2002) 35 E.H.R.R. 1, at paras. 61 and 65; Goodwin v United Kingdom (2002) 35 E.H.R.R. 18, at para.90; Glass v UK (2004) 39 E.H.R.R. 14, at para.70. 
recognised and applied in the context of medical privacy. ${ }^{60}$ Nevertheless in Gaskin v United Kingdom and MG v United Kingdom, the Court recognised that denying the applicants access to information concerning them held by the authorities infringed their vital interest in receiving information necessary to know and to understand their identity. ${ }^{61}$ In Peck v United Kingdom, the release and use, without consent, of CCTV footage of the applicant attempting suicide in a public place, was held to be a breach of his Article 8 rights, including the right to identity and personal development, and the right to establish and develop relationships with other human beings and the outside world. ${ }^{62}$ These cases are significant because, although they made no reference to informational autonomy, they concerned, to some degree, the extent of individuals' ability to exercise control over information relating to them and therefore, arguably, aspects of the same, or closely connected, privacy rights protected by Article 8 . If some aspects of this right to control were recognised as being based upon dignitary interests, a commitment to coherence in the law would justify recognising that the parallel right, in the context of medical confidentiality, is similarly underpinned. Furthermore in the recent decision of Hannover v Germany, a case concerning informational privacy and press intrusion, the European Court recognised that Article 8 protects interests in physical and psychological integrity and the development of personality. ${ }^{63}$

\section{(b) Mental integrity}

As it happens the domestic courts have not differentiated between Article 8 cases which deal with informational privacy and those which concern other aspects of Article 8 when identifying the interests at stake in breach of confidence cases. The common law has therefore been more receptive to recognising dignitary interests, such as the protection of mental integrity, than the Strasbourg authorities on medical privacy require.

Thus in $X$ (a woman formerly known as Mary Bell) v $S O$, an injunction was granted contra mundum to prevent the publication of the identity and whereabouts of Mary Bell and her daughter in order to protect Mary Bell's private interest in confidentiality and her Article 8 rights. ${ }^{64}$ Butler-Sloss $\mathrm{P}$ interpreted Article 8 as covering physical and psychological integrity, a right to personal development and a right to establish and develop relationships with other human beings and the outside world. ${ }^{65}$

60 See D.J. Harris, M. O'Boyle and C. Warbrick, Law of the European Convention on Human Rights (1995), at p.303, who warn that the outcome of any particular case under Article 8 may not tell us much beyond its own facts.

61 Gaskin v United Kingdom, Series A (1989) 12 E.H.R.R. 29, at para.49; $M G$ v United Kingdom (2003) 36 E.H.R.R. 3, at paras.27 - 29. See also Rotaru v Romania 8 BHRC 449, at para.43.

62 (2003) 36 E.H.R.R. 41, at para.57.

63 [2004] E.M.L.R. 21, at [50] and [69].

64 [2003] EWHC 1101; [2003] E.M.L.R. 37, at [38]

65 ibid., at [20], relying on Botta v Italy (1998) 26 E.H.R.R. 241, Bensaid v UK (2001) 33 E.H.R.R. 10 and $X \vee$ Netherlands (1985) 8 E.H.R.R. 235, none of which concerned informational privacy. These interests have also been recognised in domestic cases concerning information access and disclosure not founded on confidence: Re S (a child) (identification: restrictions on publication) [2003] EWCA Civ 963; [2003] 3 W.L.R. 1425, at 1449-1450 and R. (on the application 
These comments offer an instrumentalist interpretation of the values underlying Article 8. They do not necessarily offer the same basis of protection as a right to confidence based on informational autonomy. For example, where a patient opposes disclosure but it poses no risk to her mental integrity, there would be little reason to resist disclosure despite violating the patient's autonomy. Furthermore it is unclear whether a finding that these interests have been infringed is contingent on the individual suffering, or being at risk of, psychological harm as a result of disclosure, or whether mere distress would be sufficient. Butler-Sloss P., for example, stressed that the claimant would suffer substantial injury in the form of a recognisable psychiatric injury and her mental health problems would be exacerbated if the information was revealed. ${ }^{66}$ Similarly in Campbell v MGN, Baroness Hale, who also acknowledged this rationale for protecting privacy, focused not only on Ms Campbell's distress at disclosure but also at the degree of physical and mental harm she would suffer as a result of her treatment being disrupted by the disclosures. ${ }^{67}$

However, as the law has recognised that damages can be awarded in confidence for distress alone, the existence of a risk of psychological harm is likely to be more relevant when considering whether the right to confidence should be permitted to prevail over a public interest in disclosure, an issue considered in more detail subsequently. ${ }^{68}$

\section{(c) Autonomy}

Until recently, the case law on confidentiality was remarkably silent regarding the principle of respect for autonomy in contrast to decisions on consent to treatment where the principle of respect for autonomy is often cited as the moral underpinning of the law. ${ }^{69}$

Autonomy and confidentiality were first linked in Douglas v Hello! Ltd (No. 1). ${ }^{70}$ The facts are well known. Briefly, Hello! published unauthorised photographs of the celebrity wedding. The exclusive rights to photographs had been granted to $O . K$, and the exercise was designed to spoil $O . K$ 's scoop. An action was brought against Hello for breach of confidence. In the course of the hearing in the Court of Appeal for an interim injunction, Sedley L.J. indicated that the action for breach of confidence could be used to protect the claimants' privacy interests. He went on to comment that the law "can recognise privacy itself as a legal principle drawn from the fundamental value of personal autonomy." ${ }^{\prime \prime 1}$ In his view the law of confidentiality

of Rose) v Secretary of State for Health [2002] EWHC 1593; [2002] 2 F.L.R. 962, at 972-973; Re Angela Roddy (A Minor) [2003] EWHC 2927; [2004] E.M.L.R. 8.

66 [2003] E.M.L.R. 37, at [60].

67 n. 36 above, at para.157. See also Re $S$ (A Child) (Identification: Restrictions on Publication) [2003] EWCA Civ 963; [2003] 3 W.L.R. 1425, at 1450.

68 For discussion of the case-law on damages for distress see references, n.34 above.

$69 \operatorname{Re} T$ (adult: refusal of medical treatment) [1992] 4 All E.R. 649; Re C (adult: refusal of medical treatment) [1994] 1 All E.R. 819; St Georges Healthcare NHS Trust v $S$ [1998] 3 All E.R. 673; Re B v An NHS Hospital Trust [2002] 2 All E.R. 449.

70 [2001] Q.B. 967.

71 ibid, at [126]. The statement has attracted much comment but this has been directed at the apparent recognition of privacy as a legal principle rather than at 
protected privacy interests which in turn were derived from the principle of autonomy.

In the same year, R. v Department of Health, ex p. Source Informatics Ltd undermined claims that a connection could be made between the purpose of the law of confidence and the principle of respect for autonomy when the Court of Appeal ruled that there was no breach of confidence in the use of anonymised patient data. ${ }^{72}$

Simon Brown L.J., while neither expressly accepting nor rejecting the proposition that in actions for breach of confidence a patient's autonomy interests were at stake, found that the law of confidence, as it applied to personal confidences, was concerned only to protect the confider's privacy. The disclosure of anonymised information did not invade privacy and so there was no breach of confidence. He also commented that, providing that a patient's privacy was safeguarded, a patient's will would not be thwarted if information obtained from the patient was used without consent, although this clearly does not follow. ${ }^{73}$ The decision in Source Informatics illustrates that informational autonomy cannot necessarily be equated with informational privacy: the former may be violated even when the latter is not. $^{74}$

More recently in Campbell v MGN, Naomi Campbell successfully sued the Mirror for breach of confidence in relation to the publication of a story and photographs relating to her treatment for drug addiction. ${ }^{75}$ Lord Hoffmann, together with Baroness Hale, acknowledged the principle of informational autonomy and emphasised that respect for autonomy required that people should have the right to control the dissemination of information about them, commenting that "the extent to which information about one's state of health, including drug dependency, should be communicated to other people was plainly something which an individual was entitled to decide for herself." $" 76$

The significance of this judicial recognition of informational autonomy was reduced by a number of factors. Firstly the case involved disclosure of medical information by the press and, as discussed above, medical information receives a high degree of protection where such disclosures are concerned. It involves no radical change of approach to recognise the value of autonomy in this context. Secondly, Lord Hoffmann declined to explore

the link made between autonomy on the one hand and privacy and confidentiality on the other: see, for example Phillipson and Fenwick, n.13 above. Interestingly he has recently retracted the comment: Sir Stephen Sedley, "The Rocks or the Open Sea: Where is the Human Rights Act Heading?" (2005) 32 Journal of Law and Society 3, at p.16.

72 n. 33 above.

73 ibid, at 440 .

74 Laurie, n.2 above, at 223-226. See also D. Beyleveld and E. Histed, "Betrayal of Confidence in the Court of Appeal" (2000) 4 Medical Law International 277.

75 n. 36 above, Lord Nicholls and Lord Hoffmann dissenting.

$76 \mathrm{ibid}$, at para.53. See also $R$. (on the application of Marper) v Chief Constable of South Yorkshire, n.41 above, at 2217 (Baroness Hale); Re Angela Roddy (A Minor), n.65 above; Douglas v Hello (No. 3) [2005] EWCA Civ 595, at paras.79 and 81 . 
the implications of recognising autonomy more generally and so the impact this case may have on other types of information disclosure, including disclosure by the NHS, is unclear. Thirdly, the other Law Lords did not adopt Lord Hoffmann's analysis. In contrast Lord Hope, in the majority, emphasised that the case raised no new principles. ${ }^{77}$

Finally, the test for breach of confidence adopted by the other judges did not reflect the value of autonomy. The Law Lords endorsed an objective test in relation to both whether information could be considered private and whether there had been a breach of privacy through the use of such information. Information will be considered private if the person receiving it knows or ought to know it is fairly and reasonably to be regarded as confidential. ${ }^{78} \mathrm{An}$ invasion of privacy will be established if this information was disclosed when the person to whom it related had a reasonable expectation of privacy. ${ }^{79}$ At times the tests were combined ${ }^{80}$ It might be argued that these elements amount to the same thing and that there is no need to distinguish them. Lord Hope commented that if information is obviously private the person to whom it relates would have a reasonable expectation of privacy. ${ }^{81}$ However this may not follow. Medical information is obviously private but a court may not always take the view that a person can reasonably expect it to remain undisclosed. For example, in Source Informatics, Simon Brown L.J. did not consider that individual objection to the use of private information for a broad range of NHS purposes would be reasonable and inclined to the view that, in relation to such uses, no breach of confidence could arise. ${ }^{82}$

Informational autonomy would have been better respected if the test of whether there had been an invasion of privacy through the disclosure of private information had been subjective, based on an individual's actual expectations, even if the meaning of private information was objectively defined. ${ }^{83}$ The unreasonableness of expectations regarding information use would then have been relevant in considering whether an invasion of privacy was justified.

In conclusion, informational autonomy is inadequately protected by the law. While this may be due to the limited judicial recognition it has received, a

ibid, at 480 .

8 ibid, at 465 (Lord Nicholls).

79 ibid, at 466 (Lord Nicholls).

$80 \mathrm{ibid}$, at 480 (Lord Hope), at 495 (Baroness Hale).

81 ibid, at 483.

$82 \mathrm{n}$. 33 above, at 443-444. Although he also considered that the test of whether a use was reasonable should be judged by reference to the conscience of a reasonable person in the shoes of the recipient of the information, an approach that was rejected by the House of Lords. Nevertheless, the adoption of the objective test leaves patient privacy vulnerable to a court's views of what a reasonable patient would regard as unobjectionable use instead of being governed by the views of the individual affected.

83 A similar point is made by Phillipson and Fenwick, n.13 above, at p.674. Moreham makes the additional point that the test focuses on whether the claimant can expect to have their privacy respected rather than whether they think they should have their privacy respected. He asks whether the parents of a missing child have a reasonable expectation that the media will not doorstep them: N. Moreham, "Recognising Privacy in England and New Zealand" (2004) C.L.J. 555. 
more serious obstacle to its protection lies in the manner in which the domestic and European courts assess whether disclosure is justified in the public interest. The next sections will examine how the courts have approached this task and the problems they have met in doing so.

\section{THE PUBLIC INTEREST DEFENCE AND ARTICLE 8(2)}

\section{The Scope of the Defences to Disclosure}

In determining whether a disclosure of confidential information is justifiable the courts must take into account both the common law defence of the public interest and assess whether the justification falls within the grounds set out in Article 8(2). This permits disclosures which are in accordance with the law and are "necessary in a democratic society in the interests of national security, public safety or the economic well-being of the country, for the prevention of disorder or crime, for the protection of health or morals or for the protection of the rights and freedoms of others."

It is unclear how the introduction of Article 8(2) will impact on the development of the common law of confidence. One possible consequence is that the public interest defence will develop to mirror the permissible grounds for disclosure in that provision, which are probably broader than the previously recognised common law public interest grounds. ${ }^{84}$ For example Article 8(2) does not confine disclosures for the prevention of crime to serious crime and the ground of disclosure for the protection of the economic well being of the country is novel. Again, the use of information for research purposes could conceivably be justified by reference to the Article 8(2) ground of the protection of health even though it is unclear that the public interest defence previously encompassed such use. ${ }^{85}$ This correlation between the common law and Article 8 (2) may not necessarily occur: Feldman for example considers that a divergence between the public interest defence and Article 8(2) is possible since the courts are not bound by Strasbourg jurisprudence but need only take account of it. ${ }^{86}$ However what is significant is that the incorporation of Article 8(2) does not require the courts to give greater protection to informational privacy than previously, with one exception: insofar as an open-ended public interest defence of just cause or excuse had been recognised, the courts must now avoid interpreting it to be broader than Article 8(2), as interferences falling outside the terms of Article $8(2)$ would breach Article $8 .{ }^{87}$ Given the breadth of Article 8(2), this should cause no great difficulties. ${ }^{88}$

84 Brazier, n.20 above, at p.81.

85 Case, n.5 above, at pp.219-221.

86 D. Feldman, "Information and Privacy" in J. Beatson and Y. Cripps (eds.), Freedom of Expression ad Freedom of Information (2000), 299 at p.318. See also Douglas v Hello (No. 3) [2005] EWCA Civ 595 at para.53: the courts will "take account of Strasbourg jurisprudence".

87 R. Clayton and H. Tomlinson, The Law of Human Rights (2000), at paras.12.168 12.170. Lord Scott makes this point in relation to Article 10(2): $R$. (on the application of ProLife Alliance) v BBC [2004] 1 A.C. 185, at 242.

88 Fenwick and Phillipson argue that in cases of media disclosure the courts have applied an over-broad test of the public interest which goes beyond the disclosure of an iniquity to justify disclosure of facts which are merely interesting to the 


\section{THE BALANCING EXERCISE: MORE STRUCTURE, MORE PROTECTION?}

Nevertheless Feldman has argued that the need to justify interferences by reference to Article 8(2) may improve information protection because Article $8(2)$ is more scientific and certain than the common law and will require public authorities to reflect more carefully on the way rights and interests are balanced against each other. ${ }^{89}$ In contrast to the under-articulated nature of the public interest defence, Article 8(2) requires a systematic approach to the resolution of conflicts between the public interest in disclosure and the protection of medical confidentiality. Thus the European Court applies a series of tests asking was the interference: (i) in accordance with the law; (ii) in pursuit of an aim listed in Article 8(2); and (iii) necessary in a democratic society. In relation to the last requirement it must be shown that the interference: (a) met a pressing social need (b) was supported by relevant and sufficient reasons and (c) was proportionate to the aim pursued. ${ }^{90}$ In order to establish that an interference is proportionate, it must be shown that the aims pursued could not have been achieved in a less invasive manner, that the rights of the individual were taken into account and that adequate safeguards against abuse are in place. ${ }^{91}$

The case law following the HRA, however, illustrates a dilution in the strength of judicially accepted justifications for disclosure. In A Health Authority v $X$ the Court of Appeal upheld an order for disclosure of medical records to a health authority, despite patient opposition, to enable the authority to investigate whether to initiate disciplinary proceedings against a general practitioner. ${ }^{92}$ The court found that there was a public interest in the proper administration of professional disciplinary hearings analogous to the established public interest in the due administration of criminal proceedings. ${ }^{93}$ As this was an extension of the scope of this public interest, the protection afforded to confidentiality was weakened. ${ }^{94}$ In reaching its conclusion the court relied upon Woolgar v Chief Constable of the Sussex Police. However in this case disclosure to the regulatory authorities was necessary for public protection reasons and there was evidence of a real risk to the public: a patient in a nurse's care had died and following a police

public. However, as they note, in media cases no clear distinction has been drawn between the public interest in press freedom and Article 10 rights, and other grounds for disclosure in the public interest. It would be unsafe therefore to cite these as authority for a broad public interest defence in non-media cases: "National Irish Bank v RTE and Finding the Balance: Breach of Confidence Privacy and the Public Interest Test in England and Ireland" (2004) 55 NILQ 118.

89 n. 86 above, at pp. $317,324$.

$90 W$ v United Kingdom Series A 121 (1988) 10 E.H.R.R. 29, at para.60; Sunday Times v United Kingdom (No 1) (1979-80) 2 E.H.R.R. 245, at para.62.

91 Campbell v United Kingdom Series A 233-A (1993) 15 E.H.R.R. 137, at para.48; Klass v Germany Series A 28 (1979-80) 2 E.H.R.R. 214, at para.55.

92 n. 47 above. Patient opposition was noted at first instance: A Health Authority v X, n. 33 above, at 677.

93 n.47 above, at 786.

94 A similar approach was adopted in Re B [2004] EWHC 411; [2004] 2 F.L.R. 142, at 183-184. Para.2 of the Schedule to the Data Protection (Processing of Sensitive Personal Data) Order 2000, (SI 2000/417), permits disclosure for regulatory purposes if in the substantial public interest. 
investigation, the police considered it necessary to pass on the information..$^{95}$ Again, in the leading case of $W \vee$ Egdell, disclosure of a psychiatric report in breach of medical confidentiality was justified to avert a real risk of death or injury to the public if the information was not disclosed. ${ }^{96}$ More recently there have been suggestions that disclosure can proceed where there is little evidence of risk. In Re A (Disclosure of Medical Records to the GMC), a case involving the production of a child's medical records, Cazalet J. commented:
"If . . the documents sought are only medical records . . . and the court is satisfied that these are or may be relevant to the GMC carrying out its statutory duties to protect the public against possible medical misconduct, it is hard to see what grounds, if any, the parents or other parties concerned may successfully raise against any such disclosure." ${ }^{\prime 97}$

These comments suggest that disclosure will be permitted, regardless of the nature or degree of risk to the public. Although the case predated the Human Rights Act 1998, in A Health Authority v X at first instance, Munby J. endorsed and applied these comments. ${ }^{98} \mathrm{He}$ considered that disclosure was permissible on the Article 8 (2) grounds of protecting public safety, health or morals, and the rights and freedoms of others. ${ }^{99}$ However he made clear that he did not know whether there was any substance to the allegations under investigation. ${ }^{100}$ There was no discussion of the degree of risk involved, nor evidence that there was a real risk. It was sufficient that the allegations were of a serious nature and that there were adequate safeguards in place against unauthorised disclosure. ${ }^{101}$

Munby J.'s approach is consistent with Strasbourg jurisprudence. For example, although $Z \vee$ Finland is often cited as demonstrating the high priority accorded to the protection of medical information, Z's private interest in privacy only prevailed over the public interest in relation to one of her complaints. Her husband, who was HIV positive, had been charged with the attempted manslaughter of women with whom he had had sexual relations. Disclosure of Z's medical records to the prosecution, and witness orders made against her doctors, were found to be justified as a proportionate response to the pursuit of legitimate aims, namely the protection of the rights

95 n. 55 above, at 615.

96 n. 23 above, at 416, 424-425. Applied in $R$ v Crozier [1991] Crim. L.R. 138 (a real physical risk to the safety of the public if a medical report was not disclosed). See also Re L (Care Proceedings: Disclosure to Third Party) [2000] 1 F.L.R. 913 (evidence indicated that the healthcare professional presented a real risk to patients).

97 [1998] 2 F.L.R. 641, at 644.

98 n. 33 above, at 691.

99 ibid., at 690.

100 ibid., at 676

101 ibid., at 697. The allegations concerned serious dispensing of medicine, inappropriate delegation of clinical responsibility and the performance of a sterilisation without proper consent: 690. See also A v General Medical Council [2004] All E.R. (D) 246 at paras. 136-137 but contrast the approach to risk in $R$ v A Local Health Authority, ex p. LM [2000] 1 F.C.R. 736. 
and freedoms of others and the prevention of crime. ${ }^{102}$ She succeeded in establishing that the disclosure of her name and medical condition in the domestic judgment was an unjustified interference with her right to medical privacy but this was because it did not serve any public interest at all, rather than because her private right outweighed a public interest in disclosure. ${ }^{103}$ Disclosure of material from the court proceedings identifying $\mathrm{Z}$ and her medical condition ten years thence was a disproportionate response to the legitimate goal of ensuring that the administration of justice was transparent. However, even then, the possibility that the information could be legitimately disclosed at a later date was left open. ${ }^{104}$

In $T V$ v Finland the disclosure of the HIV positive status of a prisoner to prison staff directly concerned with his care was considered justified on the basis of protecting the rights and freedoms of others. The test of necessity was satisfied by demonstrating that the staff were bound by a strict obligation of confidentiality. ${ }^{105}$

In MS v Sweden, Article 8(2) was again successfully advanced to justify the disclosure of sensitive medical information. MS had made a claim for industrial injury compensation from the Social Insurance Office ("SIO"). Without her knowledge her medical records, revealing that she had had a termination some time after her work related injury, were forwarded to the SIO. This interference with her rights was found to be justified because the information obtained was potentially decisive in the granting of public funds and therefore its communication was aimed at protecting the economic well being of the country. Weakly substantiated public interest arguments prevailed even though the harm done to MS by disclosure was arguably graver than the potential harm to the community. ${ }^{106}$ Again, when determining the necessity of the interference, the Court focussed on the existence of adequate safeguards against disclosure.

These cases suggest that Article 8(2) does not present a particularly difficult obstacle for public bodies wishing to access confidential medical records. Partly this is due to the breadth of Article 8(2), which means that it is not hard for a public body to link an interference to one of the grounds contained therein, but partly it is linked to the restrictive manner in which the test of the necessity of interference has been applied. As Dickson has pointed out, in applying the test, the European Court has frequently focussed on procedural rather than substantive issues. ${ }^{107}$ Of those cases which relate to informational privacy, the majority succeed because the interferences are not in accordance with the law or there are inadequate safeguards in place against abuse rather than, for example, that the social need to which the interference was directed is insufficiently pressing. ${ }^{108}$ If these elements of the test are satisfied, it is

102 n. 54 above, at para. 110.

103 ibid., at para. 113.

104 ibid., at para. 112.

105 76A D.R. 140 (1994).

106 (1999) 28 E.H.R.R. 313, at paras. 42-44.

107 B. Dickson, Human Rights and the European Convention (1997), p.78.

108 These cases fall under respect for correspondence as well as respect for private life. See Malone v UK Series A No 82, (1984) 7 E.H.R.R. 14; Kruslin v France Series A No 176-A, (1990) 12 E.H.R.R. 547; Herczegfalvy v Austria Series A No 


\section{Northern Ireland Legal Quarterly [Vol. 56, No. 3]}

more difficult to establish an unjustified breach of Article $8^{109}$ unless the interference has had a substantial impact on the individual, interfered with the essence of the relevant right, or interfered with other protected Convention rights and important public interests. ${ }^{110}$

The use of information by the NHS is unlikely to fall foul of this restrictive application of the test of necessity. Pattenden has suggested that a broad public interest defence to the action for breach of confidence may breach the requirement that interferences must be in accordance with the law. ${ }^{111} \mathrm{~A}$ law must be sufficiently detailed to enable individuals to regulate their conduct to avoid breaching it and the public interest defence may not satisfy this. ${ }^{112}$ On the other hand the European Court has recognised that laws may be couched in vague terms to avoid rigidity and the limits of the defence are likely to be set by Article 8(2) itself. ${ }^{113}$ Furthermore, the safeguards in place against abuse are almost certainly adequate. Disclosures will be regulated by the Data Protection Act 1998, by the law of confidence, by professional obligations of confidence and possibly by the criminal law. ${ }^{114}$ Again, it is unlikely that the use of information for NHS purposes, such as auditing or management, would have a significant impact on most patients and, apart from the public interest in medical confidentiality, no other weighty public interest or Convention right would normally be affected by disclosure. ${ }^{115}$ The cases demonstrate that medical privacy does not receive a high degree of protection when demands for disclosure are made by public bodies citing the public interest and/or one of the Article 8(2) grounds for disclosure. Article 8(2) may have required a more structured approach to considering whether disclosures of private information can proceed in the public interest but it has

242-B, (1992) 15 E.H.R.R. 437; Halford v UK (1997) 24 E.H.R.R. 523; Huvig v France Series A No 176-B, (1999) 12 E.H.R.R. 528; Perry v UK (2004) 39 E.H.R.R. 76. See also R. (on the application of Szuluk) v Governor HMP Full Sutton [2004] EWHC 514; [2004] A.C.D. 45: inappropriate application of blanket rule intercepting medical communications. The scope of the right to confidentiality is broader than that of respect for correspondence however: $A D \mathrm{v}$ Netherlands 76A D.R. 157 (1994).

109 Leander v Sweden (1987) 9 E.H.R.R. 433; Chare (nee Jullien) v France, n.41 above; Klass v Germany, n.91 above; TV v Finland, n.105 above; $M S$ v Sweden n.58 above.

110 For example, intercepting detainees' correspondence strikes at the essence of the right to respect for correspondence, given their reliance on such correspondence to communicate with the outside world: see Herczegfalvy v Austria, n.108 above, at para.91. Interception of lawyer/client correspondence is also closely scrutinised due to the impact on the public interest in the due administration of justice, legal professional privilege and Article 6 rights: Niemietz v Germany Series A No. 251-B, (1992) 16 E.H.R.R. 97.

111 n.7 above, at para.11.07. Feldman thinks it unlikely: n.86 above, at p.317.

112 Doerga v Netherlands (applic.50210/99, 27 April 2004).

113 Silver v UK (1983) 5 E.H.R.R. at para.88.

114 The Health and Social Care (Community Health and Standards) Act 2003, s.136. Such safeguards were held to be adequate in $M S$ v Sweden, n.58 above and Chare (nee Jullien) v France, n.41 above.

115 Venables v News Group Newspapers Ltd [2001] 1 All E.R. 908 and Carr v Newsgroup Newspapers Ltd (unrep) Q.B.D 24 February 2005 illustrate an exception to this as Article 2 rights were at risk. 
not required a more stringent one. As a result informational autonomy is not well protected, even incidentally.

\section{Assessing the Public Interest in the Disclosure of Medical Information: Constitutional Problems}

McHarg has argued that the failure of the courts to give adequate protection to Convention rights is a result of the difficulties the judiciary have had in finding a politically defensible method of reconciling rights and the public interest. She argues that one model of adjudication adopted by the European Court involves balancing rights, conceived of as protected interests, against the public interest, conceived of as a common interest (being the interests which people in a society have in common), with the stronger prevailing. The Convention provides no objective criterion against which these different kinds of interest can be weighed and judges may not legitimately construct their own, as they are not in a position to assess the importance of a public interest, nor what serves the public interest. Only the public can do so through political institutions. The courts are limited to enquiring whether an interference is actually necessary to achieve a particular public interest. If it is, judges cannot prohibit it. To do so would result in the undemocratic and illegitimate substitution of judicial views of the appropriate balance between rights and collective goals for that of the State and its emanations. ${ }^{116}$ McHarg's argument highlights the problems the judiciary may confront when a right conflicts with a public interest and explains why, in such cases, the courts may choose to focus on the more procedural and less political aspects of the Article 8(2) test.

McHarg suggests that her analysis is relevant to courts at both European and domestic levels although the problem may be less acute domestically owing to the non-applicability of the margin of appreciation. ${ }^{117}$ This permits states some leeway in striking the balance between rights and public interests within their territories as a reflection of respect for national sovereignty and because national authorities are better placed than the Court to assess what is necessary in the national context. It has no place in domestic jurisprudence. ${ }^{118}$ Nevertheless the domestic courts do permit public authorities a discretionary area of judgment in making decisions about whether the public interest should be advanced at the expense of rights and this is partly due to a concern about the democratic legitimacy of judicial

116 A. McHarg, "Reconciling Human Rights and the Public Interest: Conceptual Problems and Doctrinal Uncertainty in the Jurisprudence of the European Court of Human Rights" [1999] 62 MLR 671, at pp. 676-680. McHarg identifies a second model of adjudication which views rights as rules with the public interest goals forming exceptions to those rules. A right will be upheld if an interference affects its core purpose. The problem of democratic legitimacy arises in this model also in relation to the Court determining the purpose of the right and in addressing interferences which affect it only peripherally: at pp.680-683. Both models are evident in the Article 8 jurisprudence under discussion but the balancing model dominates in the context of medical information.

117 ibid., at pp.695-696.

$118 R$. v DPP, exp. Kebilene [2000] 2 A.C. 326 at 380 (Lord Hope). 


\section{Northern Ireland Legal Quarterly [Vol. 56, No. 3]}

intervention. ${ }^{119}$ Furthermore the courts exercise greater deference where, as with Article 8, the right is qualified. ${ }^{120}$

The argument that it is undemocratic or illegitimate for the judiciary to permit rights to override the public interest is contested. ${ }^{121}$ Greer, for example, argues that the Convention, interpreted teleogically, produces a number of principles of interpretation including the rights principle which requires that in a democratic society Convention rights should be protected by national courts and the priority to rights principle, which requires that rights should be privileged over collective goods. ${ }^{122}$ This does not mean that rights should be treated as trumps, in the sense that they must nearly always prevail over collective welfare. ${ }^{123}$ As Ashworth points out, this interpretation is excluded by the structure of Article 8 itself which permits intervention on a broad range of grounds provided that it is necessary in a democratic society. ${ }^{124}$ However it does mean that it can be legitimate for the courts to permit a right to prevail over the collective interest.

It is suggested, therefore, that arguments about lack of democratic mandate need not prevent the courts from permitting informational privacy to prevail over public interests in disclosure. However McHarg's argument highlights problems relating to what Jowell has termed the "institutional capacity" of the courts. ${ }^{125}$ The courts' ability to privilege rights over collective interests will be limited where the assessment of the public interest lies outside their expertise and within the specialist knowledge of the public bodies concerned or when the evidence the courts would have to review to assess the weight of

119 Secretary of State for the Home Department v Rehman [2001] UKHL 47; [2003] 1 A.C. 153, at 195 (Lord Hoffmann); $R$. (on the application of Holding \& Barnes Plc) v Secretary of State for the Environment, Transport and the Regions [2001] UKHL 23; [2003] 2 A.C. 295, at 325-327 (Lord Hoffman); International Transport Roth GmbH v Secretary of State for the Home Department [2002] EWCA Civ 158; [2003] Q.B. 728, at 765 (Laws L.J.); R. (on the application of ProLife Alliance) v $B B C$, n.87 above, at 256 (Lord Walker). See also J. Waldron, "A Right-Based Critique of Constitutional Rights" (1993) 13 OJLS 18; J. Allan, "Bills of Rights and Judicial Power-A Liberal's Quandary" (1996) 16 OJLS 337; J.A.G. Griffith, "The Common Law and the Political Constitution" [2001] 117 LQR 42.

${ }^{120} R$. v DPP, ex p. Kebilene, n.118 above, at 381 (Lord Hope); International Transport Roth GmbH v Secretary of State for the Home Department, n.119 above, at 766 (Laws L.J.); $R$. (on the application of ProLife Alliance) v BBC, n.87 above, at 256 (Lord Walker); Brown v Stott [2003] 1 A.C. 681, at 720 (Lord Hope).

121 A. Ashworth, Human Rights, Serious Crime and Criminal Procedure Procedure (2002), at pp.71-72; F. Klug, "Judicial Deference under the Human Rights Act 1998" (2003) EHRLR 125; J. Jowell, "Judicial Deference: Servility, Civility or Institutional Capacity?" [2003] PL 592; A. Lester, "The Human Rights Act 1998 - Five Years On" (2004) EHRLR 258. Lord Steyn, "Deference: a Tangled Story" (2005) PL 246. It should be noted that McHarg does not necessarily subscribe to this argument but rather identifies it as following from the balancing model of adjudication adopted by the European Court of Human Rights.

122 S. Greer, "Constitutionalizing Adjudication under the European Convention on Human Rights" (2003) 23 OJLS 405, at pp.410-414.

123 As argued by R. Dworkin, Taking Rights Seriously (1977) Ch.4.

124 n.121 above, at pp.75-77.

125 n.121 above, at p.598. 
a public interest raises issues of justicability, such as evidence over resource allocation. ${ }^{126}$ In such cases the courts will be less interventionist in scrutinising interferences with private rights.

In addition, McHarg points out that although designating an interest as a right is generally understood as signifying that it can potentially override collective aims, the balancing exercise adopted by the European Court robs rights of their peremptory status. ${ }^{127}$ Rights have been treated as simply a factor in the balancing exercise which has resulted in them being "balanced away". 128

\section{INFORMATIONAL AUTONOMY, HEALTH INFORMATION AND THE PUBLIC INTEREST}

In the light of the above it might be queried whether the incipient judicial acknowledgment of the interests of informational autonomy and mental integrity will result in better protection for medical privacy particularly in relation to uses of information by the NHS for, for example, administrative, audit and management purposes. These may be justified as protecting the economic well being of the country. To reject an assertion that such disclosures should take place in the public interest, the courts would have to consider evidence concerning cost and policy content which may be regarded as non-justiciable. ${ }^{129}$ Even though there has been some indication that, as a result of the Human Rights Act 1998, the courts may be prepared to consider such evidence, the courts will not carry out a full merits review of executive and administrative decisions. As a result the extent to which that evidence will be addressed is limited. ${ }^{130}$ Again, the courts will exercise greater deference where the aims pursued through an interference are socioeconomic. ${ }^{131}$ Assessments of such public interests arguably fall outside the institutional capacity of the courts. Although there has been some indication that the courts may subject policy decisions to increased scrutiny, this has generally taken place in the course of judicial review, within the parameters of a legislative framework which has set limits on the extent to which judges

126 R. v Cambridge Health Authority, ex p. B [1995] 2 All E.R. 129, at 136; R. (on the application of Pfizer Ltd) v Secretary of State for Health [2002] EWCA Civ 1566; [2003] 1 C.M.L.R. 19, at para.17.

127 n.116 above, at p.680.

128 See also Ashworth, n.121 above, at p.65 who perceives a "balancing away" of Article 6 rights by domestic courts.

129 See cases n.126 above; $R$. (on the application of ProLife Alliance) v BBC, n.87 above, at 240 (Lord Hoffman). The extent to which the courts should treat such issues as non-justiciable is debated: D. O'Sullivan, "The Allocation of Scarce Resources and the Right to Life under the European Convention on Human Rights" [1998] PL 389; K. Syrett, "Impotence or Importance? Judicial Review in an Era of Explicit NHS Rationing" (2004) 67 MLR 289; Lord Steyn, n.121 above.

130 See, for example, the consideration of statistics and policy arguments in support of the Road Traffic Act 1988, s.172 in Brown v Stott, $n .120$ above, at 704-705 (Lord Bingham), at 709-711 (Lord Steyn).

$131 R$. v DPP, ex p. Kebilene, n.118 above, at 381; Wilson v First County Trust Ltd [2004] 1 A.C. 816, at 844 (Lord Nicholls); Evans v Amicus Healthcare Limited [2004] EWCA Civ 727; [2004] 2 F.C.R. 530, at para.65. See R.G. Lee, "Resources, Rights, and Environmental Regulation" (2005) 32 Journal of Law and Society 111, at pp.123-125. 
can intervene and provides external guidance on when intervention is justified. ${ }^{132}$ The action for breach of confidence contains no such parameters and, given this lack of guidance, the courts may exercise caution in intervening when the grounds for disclosure of patient data are socioeconomic. If the right to confidentiality was prioritised over such public interest aims, this could have unexplored ramifications for the State and the NHS in terms of cost, allocation of resources, and patient safety and could have a disruptive impact on the running of an enterprise which pursues democratically legitimated social goals. ${ }^{133}$

However the recognition of informational autonomy or mental integrity may make a difference in other types of case. For example, the disclosure of a competent elderly patient's medical information to social services, without consent, to enable social services to offer her assistance, might be justifiable on the Article 8(2) grounds of the protection of health. This is not a true collective interest but rather an articulation of the patient's welfare interests which the courts are well placed to assess. Where the interest underpinning the right to medical confidentiality is identified as the public interest, the case law examined earlier suggests that it is unlikely that a court would consider that disclosure impaired this interest. It would be relatively unproblematic therefore to find the disclosure justified and a court might wish to do so to avoid stigmatising a well intentioned healthcare professional. If the right is based on the protection of mental integrity and the patient did not suffer psychological harm as a result of disclosure, the same conclusion follows. In these circumstances, the principle of informational autonomy provides both the only and, arguably, an overriding reason for upholding confidentiality. ${ }^{134}$

Between these two extremes lies the use of information for regulatory purposes. As seen, this has been justified on the basis of public safety and the due administration of justice. It lies well within the institutional capacity of the courts to assess these public interests and the impact of permitting a right to medical confidentiality to override the public interest. A close degree of scrutiny can therefore be exercised so, for example, the courts should be satisfied that a disclosure was the least invasive interference possible in pursuit of the public interest goals. Regulatory bodies should only be able to obtain medical records where there is a real risk of injustice

132 See, for example, R. v North East Devon Health Authority, ex p. Coughlan, [2001] Q.B. 213: resource allocation quashed after reviewing provisions of the National Assistance Act 1948 and the National Health Service Act 1977.

133 As set out in the National Health Service Act 1977. In A Health Authority v X, although the Munby J. dismissed the argument that the courts should not be able to examine and veto the uses of health information by a health authority, he was, in fact, non-interventionist, permitting disclosure with little attention to the need for the disclosure: $n .33$ above, at 696-697.

134 By analogy with the law on consent to treatment, respect for autonomy bars action in a competent patient's best interests without that patient's consent: n.69 above. The current legal position on disclosures in a competent patient's best interest is unclear. It is supported by some commentators, judges and by professional guidance: Cornelius v De Taranto, n.39 above, at para.62; $H$ (A Healthcare Worker) v Associated Newspapers Limited, n.47 above, at para.28; J.K. Mason, R.A. McCall-Smith and G.T. Laurie, Law and Medical Ethics (2002), at p.244; GMC, n.32 above, at para.27. 
or public harm if the conduct of the healthcare professional is not fully investigated. ${ }^{135}$ The precise degree of risk required would vary depending upon the conception of the nature of the interest underpinning the right and the impact of the interference upon this interest. If informational autonomy was recognised, it would be acknowledged that all disclosures would interfere with the underlying interest and stronger evidence of risk would have to be advanced than if no interference was recognised. At the same time, if disclosure posed a risk to mental integrity, additional evidence of risk should be required given the potential impact of disclosure upon the individual.

\section{CONCLUSION}

Information technology developments in the NHS, including the introduction of electronic patient records, will make it easier for those who wish to access patient data to do so, whether for public interest purposes or for less beneficent reasons. The data will be vulnerable to access by a larger number of persons and it will be more complete and detailed than at present. ${ }^{136}$ The practical barriers to information access, which incidentally assisted in protecting patient privacy, are being eliminated. At the same time there is little legal resistance to disclosure where disclosure is sought by public bodies in the public interest. The combination of these developments pose a substantial risk to patient privacy, at least where information is sought by public bodies. However, given the minimal impact that most disclosures would have on individual well-being and the community need for efficient public services, the Government argues that citizens have a responsibility to yield control over personal information in the public interest. ${ }^{137}$ It can be argued that a wrongly placed emphasis on informational autonomy will be harmful to the NHS and to the public good. These arguments must be treated with caution

Those who argue for greater respect for patient autonomy would agree that rights are not absolute and must yield to the public good. The problem is how the balance should be struck and by whom. At present the law fails to give adequate weight to the privacy rights at risk. In particular, if rights are to be overridden, there should be credible evidence of harm if they are upheld. Further, it is not enough to override the right to medical privacy that there will be some cost to society through non-disclosure: the cost must be significant. ${ }^{138}$ Despite this, disclosure has been obtained where little evidence of harm to the public interest has been forthcoming.

135 A view supported by Brazier, n.20 above, at pp.63-68.

136 An example of the risk posed to patient privacy by computerised records can be found in Ashworth Hospital Authority v MGN Ltd [2001] 1 W.L.R. 515 where evidence was given that over 200 people could access patient files held on the hospital's database: at 522. Notably this case involved the leak of patient data to a national newspaper.

137 PIU, n.10 above, at para.5.04. For an analysis of the Government's approach see Perri 6, Raab and Bellamy, n.4 above, at p.116. It is shared by some of the judiciary: see Lord Steyn in Brown v Stott, n.120 above, at 707-708; and some commentators: Hagger, Woods and Barrow, n.20 above, at pp.107-109. For a critique of this approach see Ashworth, n.121 above, at pp.119-124.

138 Dworkin, n.123 above, at p.200. 
In order to safeguard privacy, patients must be granted greater control over their records. There are a number of ways this could be done, each with differing financial implications. The most expensive, and possibly most impracticable, would be to require express consent to all information uses. ${ }^{139}$ A more limited exercise of informational autonomy would be to allow patients to opt out from information disclosure. ${ }^{140}$ It has been argued that even this would be undesirable as it could corrupt the results obtained from essential research and audit, resulting in both financial and non financial costs to society. ${ }^{141}$ However there is a dearth of empirical evidence to support arguments that permitting opt-out would be harmful. It seems unlikely that this would usually cause harm given that the majority have indicated that they would permit their information to be used within the NHS at least. ${ }^{142}$ Furthermore, the very technological advances which threaten patient privacy are likely to reduce the practical difficulties and cost of recording and communicating patient opt-out. In the future it will be possible to keep a central record, accessible to all healthcare providers, of whether patients wish to opt out from information sharing. Furthermore it is anticipated that it will be possible to separate particularly sensitive information from the rest of the patient records in an "electronic envelope" and to keep audit trails of when, and by whom, patient information is accessed. ${ }^{143}$ In most cases therefore, the balance between respect for patients' rights and the public interest is likely to require that patient opt-out is observed.

The question remains regarding who should determine when a patient's choice to opt out should be overridden in favour of economic and functional arguments in favour of disclosure. It has been argued here that the courts, applying the common law of confidence, may not have the capacity to protect informational autonomy and privacy against demands for disclosure made on such grounds. Informational autonomy could receive better legal protection if there was the political will to legislate to grant patients a right to opt out of information disclosure which could only be overridden in limited circumstances. Recently the NHS and the Minister for Health issued a

139 For a review of the different approaches including costs implications see Cambridge Health Informatics, Consent-based Use of Patient Information-Input Assessment (January 2001). However recent information technology developments may make it possible to obtain, record and communicate express consent cheaply: see $n .143$ below and accompanying text.

140 An approach supported by the GMC, n.32 above, at paras.13 and 21. Opt-out arguably promotes the public interest by minimising the loss of data which might occur because of, for example, problems in seeking consent. It strikes a balance tilted in favour of disclosure whilst still respecting patient autonomy. The argument that opt-out respects patient autonomy is only valid, however, insofar as patients are aware of the uses to which their information is put and are aware that they can opt out and increasing patient awareness has proved problematic.

141 Hagger, Woods and Barrow, n.20 above, at pp.106-107.

142 n.9 above.

143 For a more detailed account of these, and other, security measures see NHS Connecting for Health, A Guide to the National Programme for Information Technology (2005) pp.20-21 and generally: http://www.connecting forhealth.nhs. uk/all_images_and_docs/NPfIT\%20brochure\%20Apr\%2005\%20final.pdf. (Last visited 10 July 2005). 
Guarantee on the use of electronic patient records which promises that in future patients will be able to veto access to their electronic records save where disclosure is compelled or it is necessary to avoid harm to a third party. ${ }^{144}$ However, while the Guarantee gives informational autonomy prominence, its practical effect is unclear. At present it amounts to no more than a statement of intent regarding future developments: how it will apply in practice is uncertain. ${ }^{145}$ It has no legal effect and it grants patients no remedies if their opt out is disregarded. ${ }^{146}$ Its influence on professional practice is also uncertain since it conflicts with the guidance provided by professional bodies, the NHS's own Code of Practice on Confidentiality, the common law and the DPA, all of which permit varying degrees of disclosure in the public interest. ${ }^{147}$ For these reasons alone it is highly unlikely that the Guarantee can be regarded as an indication of legislative intent. Furthermore, the recent initiatives which have eroded patient privacy, and the Government's communitarian ethos, suggest that the protection of medical privacy and informational autonomy, at a cost to the public interest, may not be prioritised by the legislature in the foreseeable future. ${ }^{148}$ The Government's attitude to the protection of medical privacy is ambivalent at best. It has not hesitated to legislate to set aside privacy where it has considered it necessary and so it is likely to avoid creating an additional legal obstacle to information disclosure by giving patient opt-out unequivocal legal force. It remains to be seen therefore whether the Government's rhetoric will translate into a legislative commitment to patient autonomy when the State wishes to access patient data to serve public interest purposes.

144 NHS, The Care Record Guarantee. Our Guarantee for NHS Care Records in England (2005), p.4. para.3. There is however a significant ambiguity in the Guarantee. Elsewhere it provides that by 2008 patients will be able to veto access to sensitive parts of their records save where it would put third parties at risk or when disclosure is allowed by law: at p.7. The latter phrasing allows for discretionary disclosure for public interest purposes whereas disclosure on grounds of legal compulsion only does not cover public interest disclosures, nor disclosure under the numerous statutory gateways which exist. If patient veto will be overridden where the law permits, as opposed to requires, disclosure there will be very little change to the current position.

145 The electronic patient record programme will begin to roll out in 2006.

146 Although it promises that the NHS will take disciplinary action: n.144 above, at p.5, para. 12 .

147 Department of Health, Confidentiality NHS Code of Practice (November 2003), Annex B, pp. 34-35; GMC, n.32 above.

148 Perri 6, Raab and Bellamy, n. 4 above. There is little sign that the trend to increase the number of bodies who can access identifiable patient data is on the wane: the Government has recently consulted on permitting the NHS Counter Fraud and Security Management Service access to patient data: see Department of Health, Access to Relevant Documents, Records and Data to Counter NHS Fraud: A Paper Consultation (October 2004) and Report on Consultation (May 2005) http://www.dh.gov.uk/Consultations/ResponsesToConsultations/Response sToConsultationsDocumentSummary/fs/en (last visited 16 August 2005). For criticism see also the Patient Information Advisory Group, Response (January 2005): http://www.advisorybodies.doh.gov.uk/piag/counterfraud-acccesspiagres ponse.pdf) (last visited 16 August 2005). 